\title{
The Development of Android Application-Based E- Module Learning Media on the Makassar Flute Learning Material for Year 8 Junior High School Students
}

\author{
Nurul Fathimatul Izzah*, A.M. Susilo Pradoko, Sri Wahyuni Syukur \\ Faculty of Language and Arts, Yogyakarta State University, Yogyakarta, Indonesia \\ *Corresponding author. Email: uurulfathima10@gmail.com
}

\begin{abstract}
This study aims to develop an Android application-based e-Module on the Makassar Flute learning material for Year 8 junior high school students. The development of e-Module learning media based on android application is an alternative in the use of technology. Essentially, the commonly used sources and learning media are in the form of physical books, but with advances in technology, learning media can be presented in digital form. The development model refers to the ADDIE (Analysis, Design, Development, Implementation, Evaluation) development model developed by Dick and Carry. However, in this study, it is limited to only three stages, namely ADD (Analysis, Design, Development). The development process at this stage starts from the Analysis stage by conducting needs analysis, student character analysis, analysis of hardware and software, and analysis of basic competencies. The second stage is the Design stage, which is the preparation of the flowchart and the preparation of the e-Module material and content. Then the next stage is the Development stage, in which the learning media production is carried out using the Corel Draw X4 application, which is subsequently converted to an Android-based application by utilizing the Appsgeyser application. The development of this Android-based e-Module learning media can serve as an option for the use of culture and art learning media, especially in the material of traditional musical instruments.
\end{abstract}

Keywords: Development, Learning Media, E-Module, Android Applications, Makassar Flute

\section{INTRODUCTION}

Education today is one of the most essential needs for human life. Education is one of the efforts to obtain knowledge, whether formally in the school setting, or informally through the home, community, and environment [1]. As time goes, technology development has entered the life of students in the form of devices with advanced and varied features. As a result, students today have become the generation that has an easy access to information regardless of time and place through information technology and media in these devices.

In line with the Baudillard's criticism, the modernization era is centered to the study of the role of technological media on the reality of human life in the popular culture paradigm, which generates new ideas to review the capacity of technology media in the community life in creating a consumer society. In addition, things that interest humans such as art, a house, domestic needs, etc. are demonstrated through various media in ideal models, making the boundaries of simulation and reality blurry, hence crating hyperreality where it is difficult to tell what is real and not real [2].

Technology and media can play a great role for learning [3]. Essentially, the use of technology in the learning process gives positive impacts for both students and teachers. Technology is able to present crucial information and descriptions required by students to accommodate them in exploring the knowledge and learning activities. It is therefore appropriate with the $21^{\text {st }}$ century development that the learning systems based on mobile learning have been made possible. One of the supports for success in learning is the presence of relevant learning resources. These learning resources are provided to help students from previously unaware of certain information to gaining new knowledge. The 
presence of learning resources will meet the needs of students so that learning objectives can also be met. In regard to that, advances in technology allow more effective, creative and innovative learning resources. On the other hand, learning objects refer to digital sources that can be reused to support learning [4]

There are various kinds of learning resources, one of which is modules. A module is a medium containing materials, methods and evaluations that are designed systematically and attractively to help students achieve the expected competencies. Modules generally used to be available in printed form. Today, with technology that is increasingly sophisticated and yet easy to obtain at affordable prices, modules can be presented in digital form, which is also commonly known as e-Modules [5]. E-modules can be accessed on a computer or smartphone. With the smartphone, one of the types of media that can be accessed easily by students is Android-based applications. The development of e-Module based on Android application is preferable because it can be used as a practical independent learning resource.

Arts and Culture is a subject with certain level of difficulty. According to the basic competencies in the learning materials for Year 8 students of junior high school on traditional music, students as the younger generation are expected to learn and preserve the traditional music of their local region. South Sulawesi is one of the provinces with a distinctive regional background and a diverse range of traditional music instruments. One of the traditional music instruments of South Sulawesi Selatan is the Makassar flute, also known as Bulatta. Makassar flute is a brass instrument made from thin bamboo called $a$ 'wo which makes a sound as the player blows the air into the instrument and makes the air within the instrument vibrate [6].

In this case, traditional music learning is often considered tedious and unattractive to students, especially when only print media or textbooks are used. It is therefore important to provide a more advanced alternative to the conventional textbooks by developing android-based e-Module learning media which can be downloaded on smartphones. Another consideration is that students today tend to spend more time on their phones. One of the negative impacts of smartphone is that it makes students often abandon their tasks. Therefore, this study attempts to bring the positive impacts of technology and media by developing an innovative and attractive e-Module which can be accessed through smartphones regardless of time and place.

A good module allows the students to use it easily. Learning with module as the learning material also helps students master the content faster compared to those studying without a module. Therefore, the module must appropriately depict the basic competencies that must be mastered by the students, be presented in a proper language and attractive design with illustrations [7]. In line with the material on the basic competency on traditional music and in regard to the development of technology in the $21^{\text {st }}$ century, this paper conducted a research and development study on android-based eModule learning media for the learning material on Makassar Flute for Year 8 junior high school students.

\section{LITERATURE REVIEW}

\subsection{E-Module}

E-Module is a digital, non-physical learning media that is systematically made and used for independent learning needs so that it can help students to solve problems with their own abilities and ways. E-Module is a systematically designed teaching material that refers to a specific curriculum for a specific time unit which requires an electronic device to run on, such as a computer or an Android device [8].

\subsection{Android}

The term "android" in English is defined as a "human-like robot" as represented by the Android icon of a green robot with a set of arms and legs. As an operating system, Android serves a connecting device between electronic device or smartphone users, allowing them to interact with the device and run various mobile applications [9].

\subsection{Makassar Flute}

The Makassar Flute (Suling Bulatta) is one of the traditional musical instruments of South Sulawesi. The shape of a Makassar flute is a tube which makes sound with holes for fingers used to control the pitch. This instrument makes a sound as the instrument player's blows through the mouth or sometimes the nose. The flute material is a thin bamboo named $a^{\prime}$ wo [10].

\section{RESEARCH METHOD}

The type of research used in this study was research and development. It refers to a process or stages to develop a new product or refine existing products in an accountable manner [11]. The development of androidbased e-Module learning media on the Makassar flute learning material was based on Dick and Carry's ADDIE's development model aimed to design a learning system. The model consists of five stages, namely 1) Analysis, 2) Design, 3) Development, 4) Implementation, and 5) Evaluation.

In this study, the procedure for developing androidbased e-Module learning media on the Makassar flute learning material was limited to three stages, namely 
Analysis, Design, and Development. Further elaboration can be seen below.

a) The Analysis stage is the stage of collecting information as the initial resource in making the product. In this study, the product is an android application-based e-Module learning media. At this stage, information is collected through needs analysis, analysis of student characteristics and software, and analysis of the curriculum in order to ensure the quality of the final product.

b) The Design stage mainly concerns with the designing process of the learning media by making a flowchart or a plan of the product and developing the content materials of the module.

c) The Development stage is where the designed product is finalized and completed. The product of this stage will be implemented in a trial in the next stage.

\section{RESULTS AND DISCUSSION}

In details, the stages of this research and development study were adopted from the ADDIE model, which was modified into three stages only, namely 1) Analysis, 2) Design, and 3) Development, as presented below.

\subsection{The Analysis Stage}

In this stage, analysis is done on the importance of the product development, which involves needs analysis and competency analysis, as depicted as follows:

\subsubsection{Needs Analysis}

Needs analysis is concerned with the analysis of students' characteristics, the software and hardware used, as well as the basic competencies.

\subsubsection{Analysis on Students' Characteristics}

Analysis is done on the characters and attitudes of students in learning. Learning media development must be adjusted to the needs of students today. Teacher must take advantage of the rapidly advancing technology and information media to make students more interested in the learning process. It can be observed that nearly all students have owned a smartphone and spent more time with their phones than with textbooks. Therefore, android-based learning media must be developed. In this study, the e-Module learning media based on the android application can be used by students independently whenever and wherever they want. The distribution of the learning media is quite convenient as the application can be downloaded through the available link shared via Bluetooth or email.

\subsubsection{Analysis on Software and Hardware}

The process of developing the learning media requires the appropriate software and hardware. The hardware includes PC Intel Inside RAM 4 GB, while the software used in the design and development process involves: 1) Windows 7, 2) Corel Draw X4, 3) Android Operating System, and 5) Appsgeyser.

\subsubsection{Analysis on Basic Competencies}

This stage refers to the characteristics of curriculum used in school. The development of the learning media is done based on the basic competencies that are applicable in Indonesia. This is done in order to meet the learning outcomes of Year 8 junior high school students, especially in the basic competencies of playing traditional musical instruments, as stated in the Regulation of the Minister of Education and Culture Number 24 of 2016 in basic competency 3.3. (understand the techniques of playing one of the traditional musical instruments individually) and 3.4 (play one of the traditional musical instruments individually) [12].

\subsection{The Design Stage}

The design stage of the android-based e-Module learning media consists of the making of flowchart and designing the material content for the learning media.

\subsubsection{Flowchart}

The flowchart aims to make the development process easier to follow. It depicts the content of the product in general, as seen in Figure 1 below.

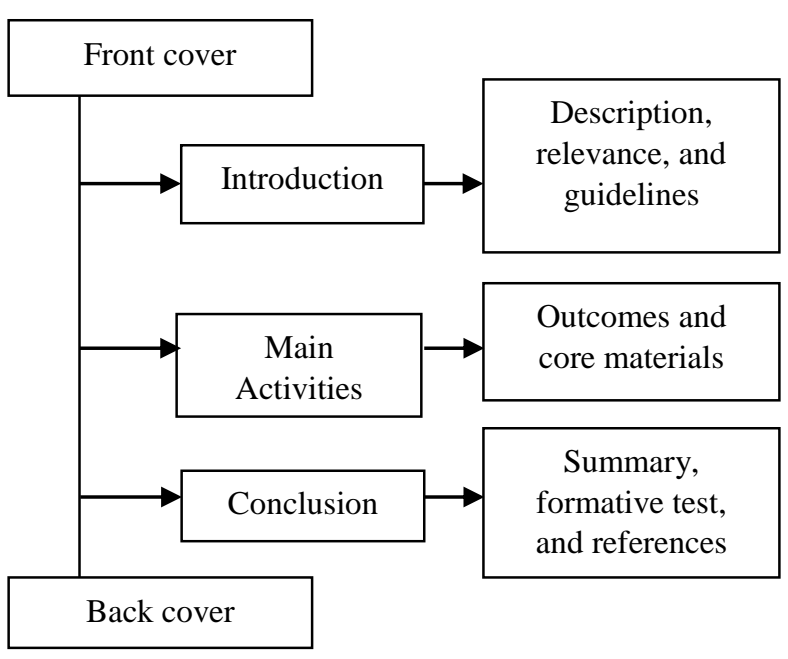

Figure 1. Flowchart Design of the Learning Media 


\subsubsection{Learning Media Design}

The initial design of the learning media is made to meet the required content system and designed in the Corel Draw X4 application by incorporating attractive images and animations. The materials are based on the Basic Competencies, specifically on the Makassar Flute Musical Instrument (Suling Bulatta). The Corel Draw X4 application drawing sheet can be seen in Figure 2 below.

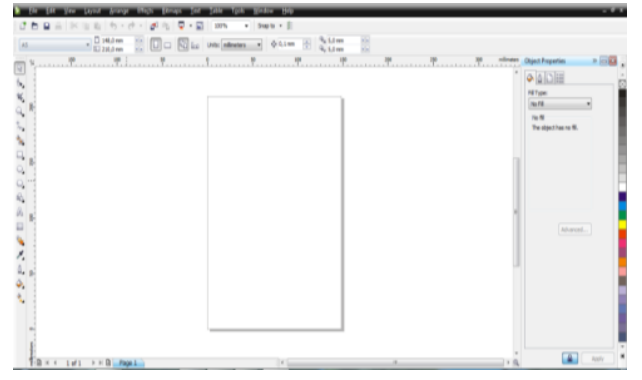

Figure 2. Display of Corel Draw X4 New Drawing Sheet

The making of e-Module is adjusted to the finished design. The result of the learning media production in the Corel Draw X4 application is as follows.

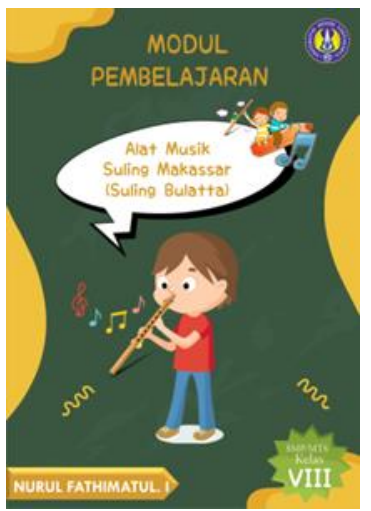

Figure 3. "Front Cover" Frame

Figure 3 contains the title of the learning material with an illustration of a kid playing the flute to represent the Makassar Flute. The cover also contains information on the Year or Grade it is intended for, as well as the name of the developer.

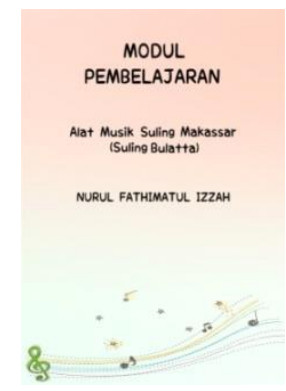

Figure 4. "Home" Frame
Figure 4 consists of the title of the learning material and the name of the developer.

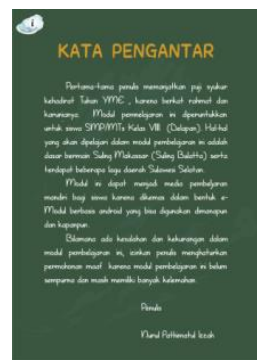

Figure 5. "Foreword" Frame

Figure 5 consists of gratitude toward God Almighty.

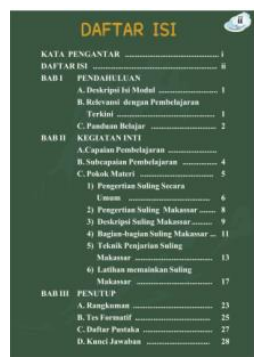

Figure 6. "Table of Content" Frame

Figure 6 is the table of content of the e-Module.

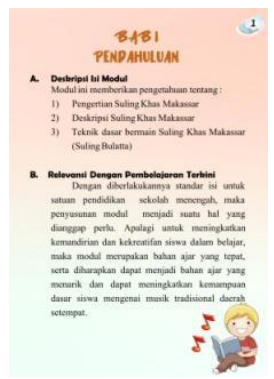

Figure 7. "Introduction" Frame

Figure 7 consists of the description, relevance with learning, and guidelines for teachers and students.

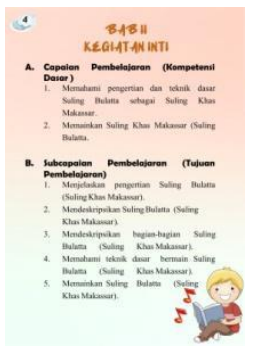

Figure 8. "Main Activities" Frame

Figure 8 consists of the basic competencies and learning objectives in the Makassar Flute learning material and the core materials. 


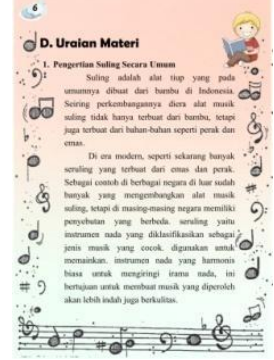

Figure 9. Frame of "Description of Learning Material"

Figure 9 consists of materials which involve the general definition, description, components, and fingering technique of the Makassar Flute.

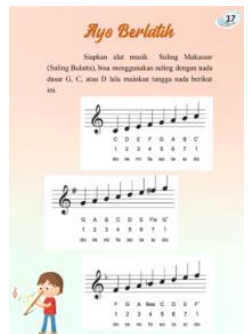

Figure 10. "Exercise" Frame

Figure 10 consists of exercise and the song reference for the South Sulawesi Traditional Song to practice and play the instrument.

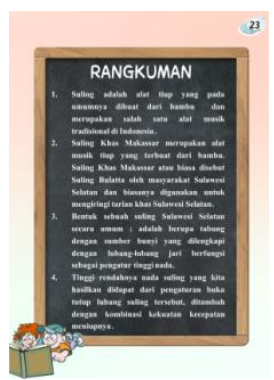

Figure 11. "Summary" Frame

Figure 11 consists of the summary of the learning material in a systematic and orderly manner.

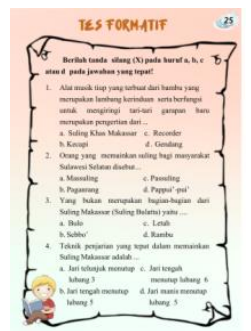

Figure 12. "Formative Test" Frame

Figure 12 consists of multiple-choice exercise items which aim to test the students' understanding on the material content.

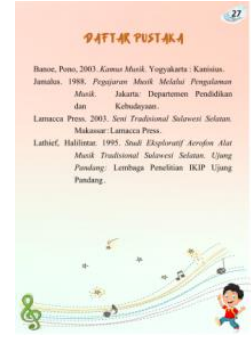

Figure 13. "References" Frame

Figure 13 consists of resources and references of materials used in the e-Module development.

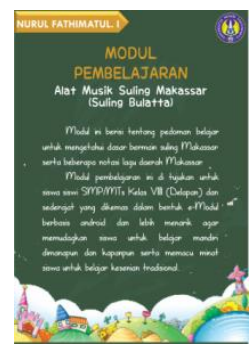

Figure 14. "Back Cover" Frame

Figure 14 consists of the name of the developer, the title of e-Module, and the general description of the eModule content.

Once the systematic development of the content is completed, the file is saved in PDF format.

\subsubsection{Product Release}

In this stage, the design is converted into an android application using the Appsgeyser application (see Figure $15)$.

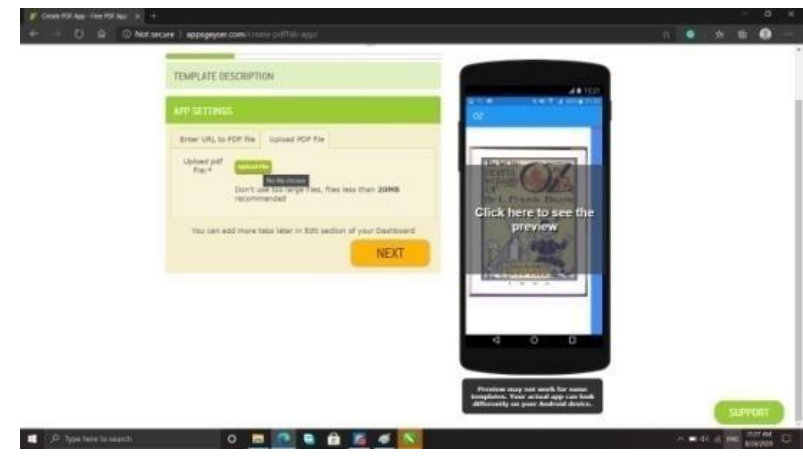

Figure 15. Display of the Appsgeyser application

Once the application is finished and exported from the Appsgeyser application, a link is made and shared to download the e-Module application on smartphones. If the download and install process is successful, the application will be ready to use. Figure 16 below shows the application display when opened. 


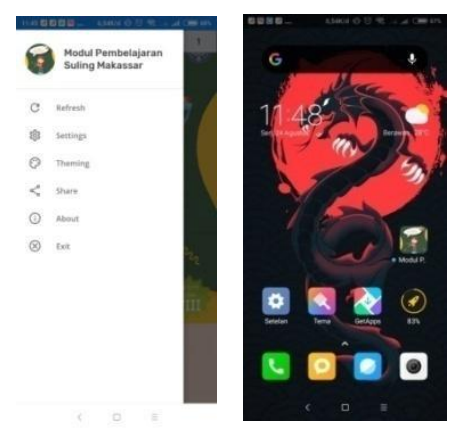

Figure 16. E-Module Display on A Smartphone

Finally, the application is ready to use on the smartphone. The link to the application download may also be shared offline via Bluetooth, which means that no internet connection is needed.

\section{CONCLUSION}

The development of android-based e-Module learning media is a form of technology application in the $21^{\text {st }}$ century where the existence of smartphones has become inevitable. The development of telecommunication has reached nearly all scopes of society, including students, who have spent more time on their smartphones more than on books. It is hoped that the e-Module learning media may serve as an innovative and interactive option which can be used anywhere and anytime to make independent learning more exciting and less tedious, especially in the traditional music learning of playing Makassar flute in the Arts and Culture subject for Year 8 junior high school students.

\section{REFERENCES}

[1] Elfachmi, Amin K. Pengantar Pendidikan [Introduction to Education]. Erlangga, 2016.

[2] Baudrillard, J. The Consumer Society: Myths and structure. SAGE Publication, 2016.

[3] Smaldino, S, E., Deborah L. Lowther, \& James D. Russel. Instructional Technology \& Media for Learning (Arif Rahman, Trans). Kencana Prenada, 2011.

[4] Parkay, F. W., Stanford, B. H. Menjadi Seorang Guru [Being a Teacher]. Jakarta: PT Indeks, 2008.

[5] Vembrianto, St. Pengantar Pengajaran Modul [Introduction to Module Teaching]. Paramita, 1985.

[6] Monoharto, G. Seni Tradisional Sulawesi Selatan [Traditional Arts of South Sulawesi]. Lamacca Press, 2003.
[7] Depdiknas. Panduan Pengembangan Bahan Ajar [Instructional Material Development Guide].

Departemen Pendidikan Nasional, 2008.

[8] Priatna, I. K., Putrama, I. M., \& Divayana, D. G. H. Pengembangan E-Modul Berbasis Model Pembelajaran Project Based Learning pada Mata Pelajaran Videografi untuk Siswa Kelas X Desain Komunikasi Visual di SMK Negeri 1 Sukasada [EModule Development Based on Project Based Learning Learning Models in Videography Subjects for Class X Visual Communication Design Students at SMK Negeri 1 Sukasada]. Jurnal Nasional Pendidikan Teknik Informatika: JANAPATI, vol. 6, no. $1, \quad 2017, \quad 70-78 . \quad$ DOI: 10.23887/janapati.v6i1.9931

[9] Firly, N. Android Application Development for Rookies with Database. Elex Media Komputindo, 2019.

[10] Lathief, Halilintar. Studi Eksploratif Aerofon Alat Musik Tradisional Sulawesi Selatan [Aerophone Exploratory Study of Traditional Musical Instruments of South Sulawesi]. Lembaga Penelitian IKIP Ujung Pandang, 1995.

[11] Sukmadinata, Nana S. Metodologi Penelitian Pendidikan [Education Research Method]. PT.Remaja Rosdakarya, 2016.

[12] Permendikbud. Permendikbud Nomor 24 Tahun 2016 Tentang Kompetensi Inti dan Kompetensi Dasar Pelajaran Pada Kurikulum 2013 Pada Pendidikan Dasar dan Pendidikan Menengah [Education and culture ministerial regulation No. 24 of 2016 on Core Competence and Basic Competence Study On Curriculum 2013 On Primary and Secondary Education]. Kementrian Pendidikan dan Kebudayaan, 2016, https://jdih.kemdikbud.go.id/arsip/Permendikbud\% 20Nomor\%208\%20Tahun\%202016.pdf 